\title{
Effects of Nano Fertilizer on Vegetative Growth of Tomato (Solanum lycopersicum L.)
}

\author{
Janmejaya Panda*, Alok Nandi, Ajoy Kumar Pattnaik, Premananda Mahapatra, \\ Nitish Kumar Jena and Asim Abhishek Swain
}

Department of Horticulture, Institute of Agricultural Sciences, Siksha 'O' Anusandhan

(Deemed To Be University), Bhubaneswar-751029, Odisha, India

*Corresponding author

\section{Keywords}

Tomato, nanofertilizer, vegetative growth, foliar application

Article Info

\section{Accepted:}

15 February 2020

Available Online:

10 March 2020

\section{A B S T R A C T}

A field experiment was conducted on tomato (cv. Utkal Pallavi) during the winter season of 2018-19, in order to evaluate the performance of new commercial nano-based, water soluble, foliar fertilizer in relation to commonly adopted water soluble foliar fertilizer with regard to vegetative growth. The experiment was laid out in the randomized block design with 8 treatments and 3 replications. Results revealed that the treatment $\mathrm{T}_{6}$ (Pramukh foliar spray@ 5g/l + RDF) was found to be the best with respect to the characters branches/plant, plant spread (E-W \& N-S), width of leaf and leaf area. $\mathrm{T}_{8}$ was maximum with respect to plant height, number of leaves/plant and length of leaf. As regards plant girth, $\mathrm{T}_{4}$ (Pramukh foliar spray @ 3g/l + RDF) was superior followed by $\mathrm{T}_{8}$ (Control) and $\mathrm{T}_{6}$ (Pramukh foliar spray @ 5g/l + RDF).

\section{Introduction}

Nano technology is a new scientific approach that includes the use of materials and equipments capable of using physical and chemical properties of a substance at molecular levels to explore the biological and material worlds in nanometer scale and use it in various carriers from medicine to agriculture. It is the science and technology of tiny things, that are less than $100 \mathrm{~nm}$ in size $\left(1 \mathrm{~nm}=10^{-9} \mathrm{~m}\right)$. Various applications of nanotechnology are seen in the fields of agriculture, medicine, air and water pollution, solar cells, electronics etc.

Basically, in the field of agriculture, use of nano nutrients based fertilizers can mitigate the problems caused by inorganic fertilizers such as environmental pollution, leaching, increasing salinity and toxicity, plant damage etc. Nano nutrients based fertilizers are highly soluble, providing actual concentration and controlled release of nutrients due to higher 
surface area with targeted activity and are also environmentally safe than the commercially used inorganic fertilizers.

Among different vegetable crops, tomato universally treated as "Protective Food" is being extensively grown as annual plant all over the world. It is rich in lycopene which is an important antioxidant. It is a very good appetizer and its soup is said to be a good remedy for patients suffering from constipation (Thamburaj and Singh, 2001). Khanm et al., (2017) found that application of 400 ppm nano $\mathrm{ZnO}$ particles on the tomato plant as seed priming or seed priming + foliar spray increased yield and growth. Priya et al., (2015) observed that 20 and 30ppm of nano phosphorus increased the germination $\%$ up to $20.83 \%$ and also increased the root length (47\%) and shoot length (33.66\%) of cowpea.

Practically, no research work has been undertaken in Odisha with particular reference to application of nano fertilizers in tomato. Hence, an experiment was conducted with the objective of analyzing the effects of nano-based commercial NPK fertilizer on vegetative growth of tomato.

\section{Materials and Methods}

The experiment was conducted in the experimental field under the Department of Horticulture, Institute of Agricultural Sciences, Siksha 'O' Anusandhan (Deemed to be University), Bhubaneswar, during the winter season of 2018-19.

Design layout - Randomized Block Design.

Number of treatments -8 and number of replications - 3

Spacing - $50 \mathrm{~cm}$ x $30 \mathrm{~cm}$

Textural class of the cultivated soil - Loamy sand

\section{Details of Treatments}

\begin{tabular}{|c|c|}
\hline Sl. No. & Treatments \\
\hline $\mathrm{T}_{1}$ & Nano-Max NPK @ 3ml/l of water foliar spray + RDF \\
\hline $\mathrm{T}_{2}$ & Nano-Max NPK @ 4ml/l of water foliar spray + RDF \\
\hline $\mathrm{T}_{3}$ & Nano-Max NPK @ 5ml/l of water foliar spray + RDF \\
\hline $\mathrm{T}_{4}$ & Pramukh @ 3g/l of water foliar spray + RDF \\
\hline $\mathrm{T}_{5}$ & Pramukh @ 4g/l of water foliar spray + RDF \\
\hline $\mathrm{T}_{6}$ & Pramukh @ 5g/l of water foliar spray + RDF \\
\hline $\mathrm{T}_{7}$ & Nano-Max NPK @ 4ml/l foliar spray + Pramukh @ 4g/l of water \\
& foliar spray + RDF \\
\hline $\mathrm{T}_{8}$ & Control $($ Only RDF) \\
\hline (RDF- Recommended Dose of Fertilizer@ $\left.125 \mathrm{~kg} \mathrm{~N}: 60 \mathrm{~kg} \mathrm{P}_{2} \mathrm{O}_{5}: 100 \mathrm{~kg} \mathrm{~K} \mathrm{O} / \mathrm{ha}\right)$
\end{tabular}

\section{Nano-max NPK}

Nano-Max NPK is totally bio-available \& bio-degradable \& completely absorbable by plant. It promotes growth of green leaves, photosynthesis, carbohydrates, oil fats \& proteins in crop. It contains multiple Organic acids (protein lacto-gluconates) based chelated major nutrients $(\mathrm{N}, \mathrm{P}, \mathrm{K})$ (min.4-44\%) along with amino acids @ 6.00\% (min.), Organic Carbon @ 10.00\% \& formulated with organic micro nutrients / trace elements - 
vitamins and probiotic. It is manufactured by J.U. Agri Science Pvt. Ltd., Indore, Madhya Pradesh.

\section{Pramukh}

Multiplex Pramukh contains Nitrogen(N) : Phosphorous (P) : Potassium(K), in the ratio of 19:19:19. This product is available in powder form. It supplies major nutrients to the plants in easily available form quickly. It is manufactured by Agriplex Pvt. Ltd., Mahalakshmi Layout, Bengaluru, Karnataka.

\section{Details of cultural operations}

\section{Sowing and transplanting}

Seeds of tomato variety Utkal Pallavi were 1st treated with Bavistin @ $2 \mathrm{~g} / \mathrm{kg}$ of seed and were sown in the nursery bed on 23rd October, 2018. Mulching was done with paddy straw. Transplanting of seedlings was done on 19th November, 2018 and irrigated immediately.

\section{Application of fertilizers}

Farm yard manure @ 25t/ha was applied at land preparation before transplanting. Inorganic fertilizers like Urea $(20 \%)+$ single super phosphate (full rate) + muriate of potash (20\%) were applied as basal. The first top dressing of urea $(40 \%)+$ muriate of potash (40\%) were applied at 15 days after transplanting. The second top dressing with the remaining $40 \%$ urea and muriate of potash was done at 30 days after transplanting. Three sprays of all the treatments of Nano-Max NPK and Multiplex Pramukh fertilizers were applied at respective doses to different subplots at the time of $1 \mathrm{st}$ and 2 nd topdressing and 15 days after 2 nd topdressing.

\section{Other cultural practices}

All other cultural practices were adopted as per recommended packages.

\section{Sampling technique}

Five plants from each plot were taken randomly excluding border plants and were tagged as sample plants for recording observations. Observations on plant height, no. of branches per plant, plant spread (EastWest and North-South), no. of leaves per plant, leaf area, length and width of fully grown leaves and plant girth were recorded periodically.

\section{Statistical analysis}

Analysis of variance method as suggested by Panse and Sukhatme (1985) was used for statistical analysis for Randomized Block Design. Standard error of mean (SEm \pm ) and critical difference (CD) at 5 percent level of significance were worked out for each character.

\section{Results and Discussion}

The field experiment was conducted during the winter season of 2018-19 to study the effects of commercial nano-based and other conventional water soluble fertilizers as foliar sprays (in different concentrations) on tomato variety Utkal Pallavi (BT-1). Observations were systematically recorded on vegetative growth parameters, results of which have been presented below and discussed simultaneously.

\section{Plant height (cm)}

A perusal of Table 1 showed that there were significant differences among the treatments in case of plant height, which ranged from $57.71 \mathrm{~cm}$ to $64.48 \mathrm{~cm}$. However, $\mathrm{T}_{8}, \mathrm{~T}_{6}, \mathrm{~T}_{4}, \mathrm{~T}_{5}$ and $\mathrm{T}_{7}$ had similar values statistically. $\mathrm{T}_{8}$ was significantly superior $(64.48 \mathrm{~cm})$ to $\mathrm{T}_{4}, \mathrm{~T}_{3}$ and $\mathrm{T}_{2}$ treatments. $\mathrm{T}_{6}, \mathrm{~T}_{4}, \mathrm{~T}_{5}$ and $\mathrm{T}_{7}$ were at par. $\mathrm{T}_{4}, \mathrm{~T}_{5}, \mathrm{~T}_{7}, \mathrm{~T}_{1}, \mathrm{~T}_{3}$ and $\mathrm{T}_{2}$ had given the similar 
results. Several researchers observed better effect of nano fertilizers on plant height (Dehkourdi and Mosavi et al., (2013); Priya et al., (2016); Anandaraj and Natarajan, (2017); Rathnayak et al., (2018). The least value $(57.71 \mathrm{~cm})$ was observed in case of the treatment $\mathrm{T}_{2}$.

\section{Branches per Plant}

Significant differences were observed among the different treatments with respect to branches per plant (Table 1). The values ranged from 5.53 to 7.13 . $\mathrm{T}_{6}$ and $\mathrm{T}_{8}$ were at par and $\mathrm{T}_{6}$ was significantly superior (7.13) to $\mathrm{T}_{3}, \mathrm{~T}_{7}, \mathrm{~T}_{5}, \mathrm{~T}_{2}, \mathrm{~T}_{4}$ and $\mathrm{T}_{1} . \mathrm{T}_{8}, \mathrm{~T}_{3}$ and $\mathrm{T}_{7}$ gave the similar results statistically. $\mathrm{T}_{3}, \mathrm{~T}_{7}, \mathrm{~T}_{5}, \mathrm{~T}_{2}$ and $\mathrm{T}_{4}$ were at par. $\mathrm{T}_{5}, \mathrm{~T}_{2}, \mathrm{~T}_{4}$ and $\mathrm{T}_{1}$ also produced similar results. This confirms the findings of Manasa and Hebsur, (2016); ElMetwally et al., (2018). The lowest value (5.53) was observed in case of $T_{1}$.

\section{Plant spread (E-W) (cm)}

It was evident from Table 1 that there were significant differences were obtained with regard to plant spread (E-W), which ranged from $53.63 \mathrm{~cm}$ to $65.50 \mathrm{~cm} . \mathrm{T}_{6}, \mathrm{~T}_{8}, \mathrm{~T}_{5}$ and $\mathrm{T}_{4}$ treatments were at par. $T_{7}, T_{3}, T_{2}$ and $T_{1}$ were significantly inferior to $\mathrm{T}_{6}$ treatment $(65.50 \mathrm{~cm}) . \mathrm{T}_{5}, \mathrm{~T}_{4}, \mathrm{~T}_{7}$ and $\mathrm{T}_{3}$ showed similar results statistically. $\mathrm{T}_{7}, \mathrm{~T}_{3}, \mathrm{~T}_{2}$ and $\mathrm{T}_{1}$ were at par. Manasa and Hebsur (2016) also made similar observations. However, $\mathrm{T}_{1}$ had the lowest value $(53.63 \mathrm{~cm})$ in this respect.

\section{Plant spread (N-S) (cm)}

It was seen from Table 1 that significant differences existed with respect to plant spread (N-S), which ranged from $58.97 \mathrm{~cm}$ to $67.43 \mathrm{~cm} . \mathrm{T}_{6}$ produced the highest $(67.43 \mathrm{~cm})$ plant spread which was at par with $\mathrm{T}_{4}, \mathrm{~T}_{8}$ and $\mathrm{T}_{5}$ in this regard. $\mathrm{T}_{5}, \mathrm{~T}_{3}$ and $\mathrm{T}_{7}$ were statistically similar. $\mathrm{T}_{2}$ and $\mathrm{T}_{1}$ were also at par. However, the smallest value $(58.97 \mathrm{~cm})$ was obtained in $\mathrm{T}_{1}$.

\section{No. of leaves per plant}

Significant differences were observed regarding no. of leaves per plant, which ranged from 58.27 to 77.40 (Table 2). The treatments $\mathrm{T}_{8}, \mathrm{~T}_{6}, \mathrm{~T}_{5}, \mathrm{~T}_{4}$ and $\mathrm{T}_{7}$ were at par. $\mathrm{T}_{8}$ (77.40) was superior to $\mathrm{T}_{1}, \mathrm{~T}_{3}$ and $\mathrm{T}_{2}$. However, $\mathrm{T}_{6}, \mathrm{~T}_{5}, \mathrm{~T}_{4}, \mathrm{~T}_{7}$ and $\mathrm{T}_{1}$ were similar statistically. This tallies with the observations of Manasa and Hebsur (2016) and Yassen et al., (2017). $\mathrm{T}_{1}, \mathrm{~T}_{3}$ and $\mathrm{T}_{2}$ also at par in this respect. $T_{2}$ treatment had lowest (58.27) no. of leaves per plant.

\section{Length of leaf $(\mathrm{cm})$}

It was evident from Table 2 that there were significant differences in case of length of leaf, which ranged from $18.98 \mathrm{~cm}$ to $23.87 \mathrm{~cm}$. $\mathrm{T}_{8}, \mathrm{~T}_{6}, \mathrm{~T}_{4}$ and $\mathrm{T}_{3}$ were at par and $\mathrm{T}_{2}, \mathrm{~T}_{7}, \mathrm{~T}_{5}$ and $T_{1}$ were significantly inferior to $T_{8} . T_{4}, T_{3}$ and $T_{2}$ were similar while $T_{7}$ and $T_{5}$ treatments also at par statistically. However, the highest $(23.87 \mathrm{~cm})$ leaf length was recorded in $\mathrm{T}_{8}$ and the lowest $(18.98 \mathrm{~cm})$ in $\mathrm{T}_{1}$ treatment.

\section{Width of leaf $(\mathrm{cm})$}

Significant differences were seen with regard to width of leaf, which ranged between $17.11 \mathrm{~cm}$ and $22.18 \mathrm{~cm}$ (Table 2). $\mathrm{T}_{6}, \mathrm{~T}_{4}, \mathrm{~T}_{8}$ and $\mathrm{T}_{3}$ treatments were similar statistically and $\mathrm{T}_{2}, \mathrm{~T}_{7}, \mathrm{~T}_{5}$ and $\mathrm{T}_{1}$ were significantly inferior to $\mathrm{T}_{6} . \mathrm{T}_{3}, \mathrm{~T}_{2}, \mathrm{~T}_{7}$ and $\mathrm{T}_{5}$ were at par. $\mathrm{T}_{2}, \mathrm{~T}_{7}, \mathrm{~T}_{5}$ and $\mathrm{T}_{1}$ were also similar. $\mathrm{T}_{6}$ performed best $(22.18 \mathrm{~cm})$ in this respect and the lowest width $(17.11 \mathrm{~cm})$ was seen in case of $\mathrm{T}_{1}$.

\section{Leaf area (sq.cm)}

It was observed from Table 2 that there were significant differences regarding leaf area of tomato plant, which ranged from 109.77 
sq.cm to 141.71 sq.cm. The treatments $\mathrm{T}_{6}, \mathrm{~T}_{8}$, $\mathrm{T}_{4}, \mathrm{~T}_{5}, \mathrm{~T}_{7}$ and $\mathrm{T}_{3}$ showed similar result and $\mathrm{T}_{2}$ and $T_{1}$ were significantly inferior than $T_{6} . T_{2}$ and $\mathrm{T}_{1}$ were at par statistically. However, $\mathrm{T}_{6}$ produced the highest (141.71 sq.cm) leaf area and $\mathrm{T}_{1}$ showed the least value $(109.77$ sq.cm) in this respect. The treatments $\mathrm{T}_{6}, \mathrm{~T}_{7}$ and $\mathrm{T}_{3}$ showed similar results. Several researchers (Hafeez et al., (2015); Jhanzab et al., (2017); Jyothi and Hebsur, (2017); Singh and Kumar, (2017); Sushmitha et al., (2018) also made similar observations regarding better effect of nano-fertilizers on leaf area.

\section{Plant girth $(\mathbf{c m})$}

It was evident from Table 2 that there were no significant differences among the treatments as regards plant girth, which ranged between $4.92 \mathrm{~cm}$ and $5.27 \mathrm{~cm}$. The highest value $(5.27 \mathrm{~cm})$ was seen in case of $\mathrm{T}_{4}$ followed by $\mathrm{T}_{8}$ and $\mathrm{T}_{6}$. The lowest value $(4.92 \mathrm{~cm})$ was observed in case of $\mathrm{T}_{2}$ treatment.

Table.1 Effects of nano-fertilizer on plant height, branches/plant, plant spread (E-W) and plant spread $(\mathrm{N}-\mathrm{S})$ of tomato

\begin{tabular}{|c|c|c|c|c|c|}
\hline \multicolumn{2}{|r|}{ Treatments } & \multirow{2}{*}{$\begin{array}{c}\text { Plant height } \\
(\mathbf{c m})\end{array}$} & \multirow{2}{*}{$\begin{array}{c}\text { Branches } \\
\text { per plant } \\
5.53\end{array}$} & \multirow{2}{*}{$\begin{array}{c}\text { Plant spread } \\
(\text { E-W) }(\mathbf{c m}) \\
53.63\end{array}$} & \multirow{2}{*}{$\begin{array}{c}\text { Plant spread } \\
(\mathbf{N}-S)(\mathbf{c m})\end{array}$} \\
\hline $\mathbf{T}_{1}$ & $\begin{array}{l}\text { Nano-Max NPK } \\
(3 \mathrm{ml} / 1)+\mathrm{RDF}\end{array}$ & & & & \\
\hline $\mathbf{T}_{2}$ & $\begin{array}{l}\text { Nano-Max NPK } \\
(4 \mathrm{ml} / \mathrm{l})+\mathrm{RDF}\end{array}$ & 57.71 & 5.87 & 55.64 & 59.51 \\
\hline $\mathbf{T}_{\mathbf{3}}$ & $\begin{array}{l}\text { Nano- Max NPK } \\
(5 \mathrm{ml} / \mathrm{l})+\mathrm{RDF}\end{array}$ & 58.36 & 6.40 & 57.47 & 61.03 \\
\hline $\mathbf{T}_{4}$ & $\begin{array}{l}\text { Pramukh }(3 g / l)+ \\
\text { RDF }\end{array}$ & 61.55 & 5.80 & 61.29 & 65.94 \\
\hline $\mathbf{T}_{5}$ & $\begin{array}{l}\text { Pramukh }(4 g / l)+ \\
\text { RDF }\end{array}$ & 61.17 & 5.87 & 61.82 & 64.49 \\
\hline $\mathbf{T}_{6}$ & $\begin{array}{l}\text { Pramukh }(5 g / l)+ \\
\text { RDF }\end{array}$ & 63.45 & 7.13 & 65.50 & 67.43 \\
\hline $\mathbf{T}_{7}$ & $\begin{array}{l}\text { Pramukh }(4 \mathrm{~g} / \mathrm{l})+ \\
\text { Nano-Max NPK } \\
(4 \mathrm{ml} / \mathrm{l})+\mathrm{RDF}\end{array}$ & 59.67 & 6.40 & 57.64 & 60.59 \\
\hline $\mathbf{T}_{8}$ & $\begin{array}{l}\text { Control (No spray + } \\
\text { RDF) }\end{array}$ & 64.48 & 6.67 & 65.15 & 65.57 \\
\hline & SE $(m) \pm$ & 1.59 & 0.20 & 1.83 & 1.43 \\
\hline & $\mathrm{CD}(0.05)$ & 4.81 & 0.60 & 5.56 & 4.33 \\
\hline & $\operatorname{CV}(\%)$ & 4.53 & 5.53 & 5.32 & 3.93 \\
\hline
\end{tabular}


Table.2 Effects of nano-fertilizer on number of leaves/plant, length and width of leaf, leaf area and plant girth of tomato

\begin{tabular}{|c|c|c|c|c|c|c|}
\hline \multicolumn{2}{|r|}{ Treatments } & \multirow{2}{*}{$\begin{array}{c}\text { No. of } \\
\text { Leaves per plant } \\
64.80\end{array}$} & \multirow{2}{*}{$\begin{array}{c}\begin{array}{c}\text { Length of } \\
\text { leaf }(\mathbf{c m})\end{array} \\
18.98\end{array}$} & \multirow{2}{*}{$\begin{array}{l}\text { Width of } \\
\text { leaf }(\mathbf{c m}) \\
17.11\end{array}$} & \multirow{2}{*}{$\begin{array}{c}\begin{array}{c}\text { Leaf area } \\
\text { (sq.cm) }\end{array} \\
109.77\end{array}$} & \multirow{2}{*}{$\begin{array}{c}\begin{array}{c}\text { Plant girth } \\
\text { (cm) }\end{array} \\
5.12\end{array}$} \\
\hline $\mathbf{T}_{1}$ & $\begin{array}{l}\text { Nano-Max NPK } \\
(3 \mathrm{ml} / \mathrm{l})+\mathrm{RDF}\end{array}$ & & & & & \\
\hline $\mathbf{T}_{2}$ & $\begin{array}{l}\text { Nano-Max NPK } \\
(4 \mathrm{ml} / \mathrm{l})+\mathrm{RDF}\end{array}$ & 58.27 & 20.76 & 19.11 & 112.09 & 4.92 \\
\hline $\mathbf{T}_{3}$ & $\begin{array}{l}\text { Nano- Max NPK } \\
(5 \mathrm{ml} / \mathrm{l})+\mathrm{RDF}\end{array}$ & 59.93 & 22.32 & 20.62 & 122.51 & 4.97 \\
\hline $\mathbf{T}_{4}$ & $\begin{array}{l}\text { Pramukh }(3 g / l)+ \\
\text { RDF }\end{array}$ & 68.53 & 23.25 & 21.92 & 129.41 & 5.27 \\
\hline $\mathbf{T}_{5}$ & $\begin{array}{l}\text { Pramukh }(4 g / l)+ \\
\text { RDF }\end{array}$ & 70.60 & 19.94 & 18.45 & 126.93 & 4.94 \\
\hline$T_{6}$ & $\begin{array}{l}\text { Pramukh }(5 g / l)+ \\
\text { RDF }\end{array}$ & 73.00 & 23.61 & 22.18 & 141.71 & 5.15 \\
\hline $\mathbf{T}_{7}$ & $\begin{array}{l}\text { Pramukh }(4 \mathrm{~g} / \mathrm{l})+ \\
\text { Nano-Max NPK } \\
(4 \mathrm{ml} / \mathrm{l})+\mathrm{RDF}\end{array}$ & 67.47 & 20.05 & 18.68 & 124.47 & 4.98 \\
\hline $\mathbf{T}_{8}$ & $\begin{array}{l}\text { Control (No spray } \\
+\mathrm{RDF})\end{array}$ & 77.40 & 23.87 & 21.91 & 132.92 & 5.25 \\
\hline & $\mathrm{SE}(\mathrm{m}) \pm$ & 4.07 & 0.87 & 0.89 & 7.68 & 0.17 \\
\hline & $\mathrm{CD}(0.05)$ & 12.35 & 2.65 & 2.71 & 23.28 & NS \\
\hline & CV(\%) & 10.45 & 7.01 & 7.73 & 10.64 & 5.81 \\
\hline
\end{tabular}

The treatment $\mathrm{T}_{6}$ (Pramukh foliar spray@ 5g/l $+\mathrm{RDF}$ ) was found to be the best with respect to the characters branches/plant, plant spread (E-W \& N-S), width of leaf and leaf area. $\mathrm{T}_{8}$ (Control) was the best with respect to plant height, number of leaves/plant and length of leaf. $\mathrm{T}_{4}$ (Pramukh foliar spray @ 3g/l + RDF) was superior as regards plant girth followed by $\mathrm{T}_{8}$ (Control) and $\mathrm{T}_{6}$ (Pramukh foliar spray @ $5 \mathrm{~g} / 1+\mathrm{RDF})$.

\section{References}

Anandaraj, K. and Natarajan, N., 2017. Effect of nano particles for seed quality enhancement in onion [Allium cepa (Linn) cv. CO (On)]5. Int. J. Curr. Microbiol. App. Sci., 6(11): 3714-3724.

Dehkourdi, E. H. and Mosavi, M., 2013. Effect of anatase nano particles $\left(\mathrm{TiO}_{2}\right)$ on parsley seed germination
(Petroselinum crispum) in vitro. Biol. Trace Elem. Res., 155: 283-286.

El-Metwally, I. M., Abo-Basha, D. M. R. and Abd El-Aziz, M. E., 2018. Response of peanut plants to different foliar applications of nano-iron, manganese and zinc under sandy soil conditions. Middle East J. Appl. Sci., 8(2): 474-482.

Hafeez, A., Razzaq, A., Mahmood, T. and Jhanzab, H. M., 2015. Potential of copper nano particles to increase growth and yield of wheat. J. Nanosci. Adv. Tech., 1(1): 6-11.

https://actascientific.com/ASAG/pdf/ASAG02-0108.pdf

https://homeguides.sfgate.com/disadvantagesinorganic-fertilizer-64756.html https://www.indiamart.com/proddetail/nanomax-npk-fertilizer-12188041548.html https://www.indiamart.com/proddetail/pramu kh-fertilizer-19104737930.html 
Jhanzab, H. M., Razzaq, A., Jilan,i G., Rehman, A., Hafeez, A. and Yasmeen, F., 2015. Silver nano particles enhance the growth, yield and nutrient use efficiency of wheat. Int. J. Agron. and Agric. Res., 7(1): 15-22.

Jyothi, T. V. and Hebsur, N. S., 2017. Effect of nano fertilizers on growth and yield of selected cereals - A review. Agric. Rev., 38(2): 112-120.

Kalloo, G., Banerjee, M. K., Tewari, R. N. and Pachauri, D. C., 2019. Tomato (Lycopersicon esculentum Mill.) In: Textbook of vegetables, tuber crops and spices, 8th reprint (Eds.) S. Thamburaj and N. Singh. Directorate of Knowledge Management in Agriculture, Indian Council of Agricultural Research, New Delhi. Pp. 10-19.

Khanm, H., Vaishnavi, B. A., Namratha, M. R. and Shankar, A. G., 2017. Nano zinc oxide boosting growth and yield in Tomato: the rise of "nano fertilizer era". Int. J. Agric. Sci. and Res., 7(3): 197206.

Manasa, V. and Hebsur, N. S., 2016. Effect of foliar application of nano iron oxide formulations on morphological parameters and chlorophyll content in groundnut. Adv. Life Sci., 5(12): 52005204.

Panse, V. G. and Sukhatme, P. V., 1985. Statistical Methods for Agricultural Workers, Indian Council of Agricultural Research, New Delhi.

Priya, B., Srinivasarao, M. and Mukherjee, S.,
2015. Screening of phosphorus nano particle concentration based on their effects at germination \& seedling level in mung, urd and cowpea. Vegetos, 28(4): 169-178.

Priya, B., Srinivasarao, M., Satyanarayana, N. H., Mukherjee, S., Das, B. and Sarkar, K. K., 2016. Effect of metal based nano particles $\left(\mathrm{ZnO}\right.$ and $\left.\mathrm{TiO}_{2}\right)$ on germination and growth of cowpea seedling. The Ecoscan, 9: 359-365.

Rathnayaka, R. M. N. N., Mahendran, S., Iqbal, Y. B., Rifnas, L. M., 2018. Influence of urea and nano-nitrogen fertilizers on the growth and yield of rice (Oryza sativa L.) cultivar "Bg 250". Int. J. Res. Pub., 5(2): 1-7.

Singh, M. D. and Kumar, B. N. A., 2017. Bio efficacy of nano zinc sulphide $(\mathrm{ZnS})$ on growth and yield of sunflower (Helianthus annus L.) and nutrient status in the soil. Int. J. Agric. Sci., 9(6): 3795-3798.

Sushmitha, B. P., Hanumanthappa, D. C., Mudalagiriyappa, Kalyanamurthy, K. N. and Shree Harsha Kumar, S. S., 2018. Response of groundnut (Arachis hypogaea L.) to nano boron. Green Farming, 9(5): 925-927.

Yassen, A., Abdallah, E., Gaballah, M. and Zaghloul, S., 2017. Role of silicon dioxide nano fertilizer in mitigating salt stress on growth, yield and chemical composition of cucumber (Cucumis sativus L .). Int. J. Agric. Res., 12: 130135.

\section{How to cite this article:}

Janmejaya Panda, Alok Nandi, Ajoy Kumar Pattnaik, Premananda Mahapatra, Nitish Kumar Jena and Asim Abhishek Swain. 2020. Effects of Nano Fertilizer on Vegetative Growth of Tomato (Solanum Lycopersicum L.). Int.J.Curr.Microbiol.App.Sci. 9(03): 1980-1986. doi: https://doi.org/10.20546/ijcmas.2020.903.230 